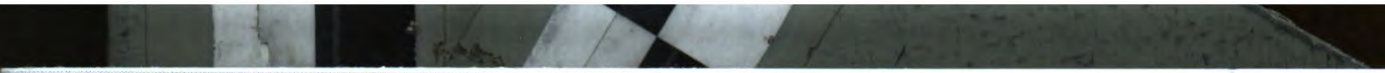

\title{
ALD-STKS
} U

413 .A66 S76 2004
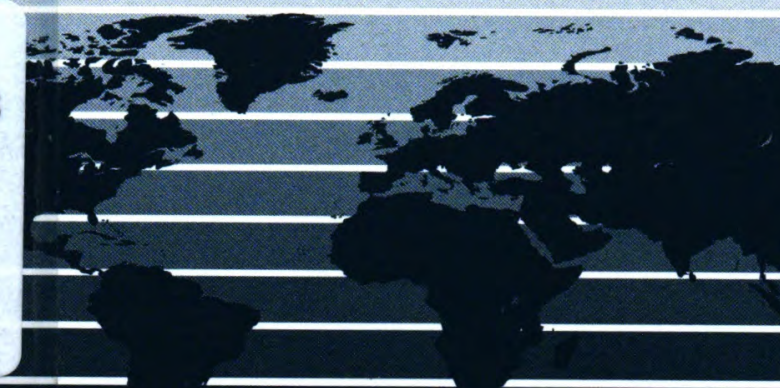

-

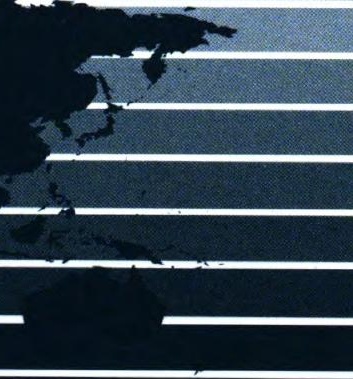

Strategic Studies Institute SD

\section{BRITAIN'S ROLE \\ IN U.S. MISSILE DEFENSE}

Jeremy Stocker 